\title{
PREPARASI DAN KARAKTERISASI KOMPLEKS KITOSAN HIDROGEL-TEMBAGA(II)
}

\author{
Risfidian Mohadi, Nurlisa Hidayati, Melany N.R \\ Jurusan Kimia, Fakultas MIPA Universitas Sriwijaya \\ Email : risf5@yahoo.com
}

\begin{abstract}
Research about preparation and characterization complex of chitosan hydrogelcopper(II) had been done. Chitosan hydrogel was obtained from deacetylation of chitin which was isolated from crab shells. Characterization included determination of N-total, $\mathrm{C}_{\text {organic }}$, deacetylation degree, and FTIR spectroscopy. The results of research showed that obtained chitosan had 7,9571\% $\mathrm{N}$-total, $2,767 \% \mathrm{C}_{\text {organic }}$, and 71,486\% deacetylation degree. FTIR spectrum of chitosan showed the increasing in percentage of transmitant from $\mathrm{C}=\mathrm{O}$ group and the shifting in wavenumber from 1561,5 to $1563 \mathrm{~cm}^{-1}$ indicated $\mathrm{N}$ $\mathrm{H}$ bending. Generally, FTIR spectrum of chitosan hydrogel showed the shifting to higher wavenumbers caused by changing in bond angles of chitosan group. FTIR spectrum of chitosan hydrogel-copper(II) complex showed that absorption regions of N$\mathrm{H}$ group becoming wide and the shifting in wavenumber from 1594,74 to $1542,9 \mathrm{~cm}^{-1}$ which indicated $\mathrm{N}-\mathrm{H}$ bending because of copper(II) bonding to N-group of chitosan.
\end{abstract}

Key words : chitin, chitosan hydrogel-copper(II)

\section{PENDAHULUAN}

Kitosan merupakan polimer dari proses deasetilasi kitin yang mempunyai sifat tidak beracun dan dapat terbiodegradasi. Kitosan juga memiliki gugus fungsi yang dapat digunakan sebagai ligan untuk berkoordinasi dan bereaksi. Selain karena karakteristik kitosan yang istimewa, pemanfaatan kitosan juga didukung oleh bahan baku berupa cangkang kepiting yang berlimpah keberadaannya di alam. Kitosan juga bersifat polielektrolit sehingga dapat dengan mudah berinteraksi dengan zatzat organik lainnya seperti protein. Kitosan relatif lebih banyak digunakan pada berbagai bidang industri terapan dan industri kesehatan daripada kitin (Marganof, 2002).

Berdasarkan pola difraksi X-ray, konformasi utama dari kompleks kitosan dapat dikelompokkan menjadi dua tipe, yaitu :

1. Tipe I, mempunyai struktur perpanjangan dari 2 lipatan spiral dengan pengulangan sekitar $10 \AA$ aksial.

2. Tipe II, mempunyai struktur perpanjangan dari 8 lipatan spiral dengan pengulangan sekitar $40 \AA$ aksial.

Kompleks kitosan dengan asam monokarboksilat seperti asam formiat dan asam asetat dibentuk pada keadaan padat. Kompleks tersebut dapat mengubah konformasi molekul kitosan dari struktur tipe I menjadi tipe II pada bentuk hidrat dan sekaligus mengubah konformasi molekulnya dari struktur type II menjadi tipe I pada bentuk anhidrat (Okuyama, 2000). 


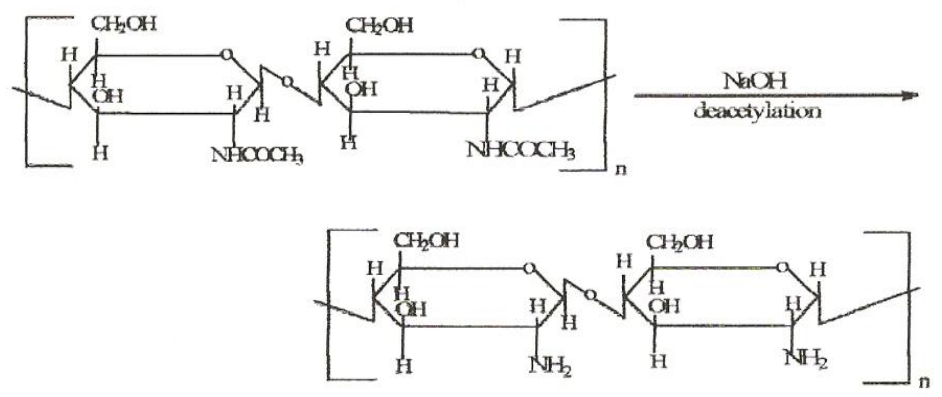

Gambar 1. Proses deasetilasi kitin menjadi kitosan (Kumar, 2000)

Kitosan bersifat hidrofilik, dapat terbiodegradasi, dan anti-bakteri. Kitosan telah digunakan di berbagai bidang industri seperti industri makanan aditif, kosmetika, material pertanian, dan anti bakterial. Kitosan juga sering digunakan sebagai adsorben pada ion logam transisi dan spesies organik. Hal ini disebabkan oleh adanya gugus amino $\left(-\mathrm{NH}_{2}\right)$ dan gugus hidroksil ($\mathrm{OH})$ dari rantai kitosan yang dapat dijadikan sebagai tempat untuk berkoordinasi dan bereaksi. Atom nitrogen pada gugus amina menyediakan pasangan elektron bebas yang dapat bereaksi dengan kation logam. Gugus amina primer pada kitosan memungkinkan kitosan menjadi mudah mengalami modifikasi kimia dan membentuk garam dengan asam. Pada $\mathrm{pH}$ asam, gugus amino terprotonisasi sehingga meningkatkan kelarutan kitosan yang bersifat tidak larut dalam pelarut alkali dan pada $\mathrm{pH}$ netral (Guibal, 2004).

Parameter dasar yang dapat digunakan untuk karakteristik kitosan adalah derajat deasetilasi, berat molekul polimer, dan sifat kristalnya. Parameter ini mempengaruhi sifat fisika-kimianya. Derajat deasetilasi pada kebanyakan kitosan biasanya lebih rendah dari $95 \%$. Produk dengan derajat deasetilasi yang cukup tinggi lebih diminati untuk aplikasi biomedis. Untuk memperoleh hasil yang diinginkan, parameter ini dapat dimodifikasi. Derajat deasetilasi dapat diturunkan dengan reasetilasi sedangkan berat molekul melalui depolimerisasi menggunakan asam.

\section{Kitosan Hidrogel}

Hidrogel merupakan jaringan polimer hidrofilik yang dapat menyerap sejumlah besar air sehingga dapat menyebabkan peningkatan volume secara drastis. Sifat fisikokimia dari hidrogel tidak hanya tergantung dari struktur molekul, struktur gel dan banyaknya ikatan silang, tetapi juga dipengaruhi oleh kandungan dan keadaan air di dalam hidrogel tersebut. Hidrogel mempunyai sifat yang dapat mengembang dan menyusut pada kondisi $\mathrm{pH}$ tertentu. Kemampuannya yang peka terhadap perubahan $\mathrm{pH}$ menjadikan kitosan berpotensial sebagai pembawa obat spesifik ke tempat yang spesifik juga. Pelepasan obat dari hidrogel tergantung dari struktur dan sifat kimianya sebagai respon dari $\mathrm{pH}$. Polimer ini diharapkan dapat tinggal sesaat di lingkungan tertentu untuk mengatur pelepasan obat. Penggunaan kitosan didukung juga dengan sifatnya yang dapat dimodifikasi atau diturunkan sehingga diharapkan dapat memperoleh polimer pengontrol pelepasan obat yang diinginkan (Kumar,2000).

Secara sederhana, hidrogel dibagi ke dalam tiga kelompok sesuai dengan jaringan aslinya, yaitu : 
1. Jaringan yang berbentuk jerat

Tipe ini terbatas penggunaannya karena kurangnya kekuatan mekanikal dan mempunyai kecenderungan untuk tidak larut. Selain itu, tipe ini juga tidak menunjukkan sifat yang mudah dikontrol seperti respon terhadap perubahan lingkungan fisikokimia seperti $\mathrm{pH}$ dan temperatur.

2. Jaringan yang berbentuk ikatan silang secara kovalen

Tipe ini merupakan jenis yang paling sering digunakan. Pada tipe ini, rantai polimer dihubungkan

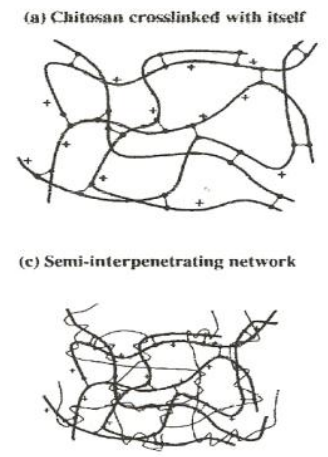

oleh ikatan silang. Jaringan tipe ini, dapat digunakan untuk pengkompleksan logam pada medium asam. Kapasitas penyerapan tergantung dari luasnya jaringan tersebut, dimana semakin luas jaringan maka akan semakin menurun kemampuan untuk menyerap.

3. Jaringan yang dibentuk dari jaringan jerat dan ikatan silang Jaringan ini dimodifikasikan dari jaringan jerat dan ikatan silang, dimana sifatnya antara tipe jaringan yang pertama dan yang kedua.

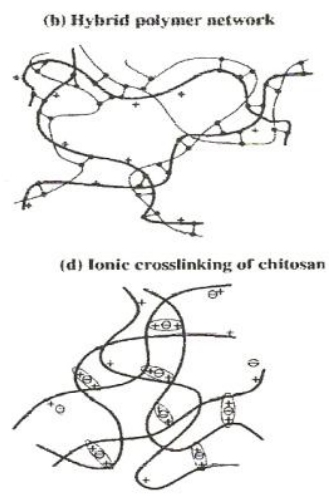

Gambar 2. Struktur jaringan ikatan silang (Berger, 2004)

Pembagian hidrogel tidak mempunyai batasan tertentu melainkan ada suatu rangkaian kesatuan mulai dari jaringan yang berbentuk jerat sampai jaringan yang berbentuk ikatan silang secara kovalen (Berger, 2004).

Hidrogel yang berikatan secara kimia maupun fisika, memiliki kelebihan dan peranan masing-masing. Hidrogel yang berikatan secara fisika digunakan untuk penggunaan yang relatif cepat karena ikatannya yang cukup lemah sehingga dalam media asam yang encer pada waktu tertentu sudah mengalami pembengkakan dan akhirnya melarut. Lain halnya dengan hidrogel yang berikatan secara kimia, karena ikatannya kuat atau sulit diubah- ubah lagi sehingga dalam kondisi asam masih bisa bertahan cukup lama.

\section{Interaksi tembaga(II) dengan Kitosan}

Tembaga(II) merupakan salah satu unsur essensial di dalam tubuh manusia. Logam yang dapat dijadikan atom pusat ini, berperan besar dalam mengatur transpor air di dalam tubuh manusia. Penggunaan tembaga (II) dalam bentuk kompleks dengan protein telah banyak dimanfaatkan bagi kesehatan manusia. Selain pada manusia tembaga(II) juga merupakan penyusun sel-sel darah pada hewan tingkat rendah dan juga pada tumbuhan. Pada hewan tingkat rendah, tembaga merupakan unsur yang cukup berperan, karena darah pada hewan 
tingkat rendah banyak mengandung tembaga. Protein hemosianin dari kompleks tembaga-protein, diketahui sebagai pembawa oksigen pada sejumlah invertebrata. Selain pada hewan tingkat rendah, tembaga juga merupakan unsur logam terbanyak nomor tiga pada tubuh manusia setelah besi dan seng. Pada tubuh manusia, tembaga juga diyakini dapat mengatur kadar air dalam darah. Sekarang ini oksidasi cytochrome dan enzim yang mengandung tembaga juga banyak dimanfaatkan.

Berdasarkan teori Hard and Soft Acid and Bases (HSAB) (Pearson, 1963), kitosan hidrogel dapat berinteraksi membentuk kompleks dengan tembaga(II) karena merupakan pasangan asam dan basa madya. Karena keistimewaan karakteristik kitosan hidrogel dan didukung kococokkan tembaga(II) sebagai pengompleksnya maka dirasa perlu mensintesis kompleks kitosan hidrogel-tembaga(II) yang diharapkan dapat diaplikasikan di bidang kesehatan.

Kitosan mempunyai bentuk fisik dan kimia yang menarik, sehingga kitosan dapat digunakan sebagai agen pengkelat logam serta mempunyai kemampuan mengikat lebih dari 1 $\mathrm{mmol} / \mathrm{g}$ untuk beberapa logam berat dan beracun. Penyerapan ion $\mathrm{Cu}^{2+}, \mathrm{Hg}^{2+}$, $\mathrm{Ni}^{2+}$ dan $\mathrm{Zn}^{2+}$ oleh kitosan dengan beranekaragam ukuran $(210-1000 \mu \mathrm{M})$ diketahui sebesar 222, 815, 75, dan 164 $\mathrm{mg} / \mathrm{g}$. Ukuran partikel tidak memberikan pengaruh yang besar terhadap penjenuhan kapasitas penyerapan. Tetapi, peningkatan temperatur dapat mengurangi penjenuhan kapasitas penyerapan (Varma, 2004).

Penyerapan ion-ion logam oleh kitosan terjadi dengan pembentukkan kompleks. Berdasarkan kemampuannya membentuk kompleks dengan ion logam, kitosan sering dimanfaatkan seperti pembentukkan kompleks kitosan hidrogel dengan tembaga(II) di bidang kesehatan. Proses pembentukkan kompleks kitosan dengan tembaga(II) dipengaruhi oleh beberapa faktor seperti keadaan $\mathrm{pH}$, temperatur, dan waktu stabil kompleks (Guibal, 2004). Berdasarkan eksperimen yang telah dilakukan oleh Kopecky (2005) diketahui bahwa kitosan dapat menyerap tembaga(II) pada lingkungan yang mempunyai kisaran $\mathrm{pH} 4$ dengan temperatur $\pm 25^{\circ} \mathrm{C}$ dengan waktu stabil untuk kompleks ini dapat mencapai 1224 jam.

\section{METODE PENELITIAN}

\section{Isolasi kitosan serta karakterisasinya}

Isolasi kitosan diawali dengan mengisolasi kitin dari cangkang kepiting yang dilakukan melalui dua tahap yaitu deproteinisasi dan demineralisasi. Proses deproteinisasi dilakukan dengan mencampurkan cangkang kepiting dengan $\mathrm{NaOH} 3,5 \%$ dengan perbandingan 1:10. Campuran diaduk dan dipanaskan pada temperatur $65^{\circ} \mathrm{C}$ selama 2 jam dan setelah itu didinginkan. Hasil yang diperoleh disaring dan dicuci dengan air demineral sampai netral, lalu dikeringkan dalam oven pada temperatur $60^{\circ} \mathrm{C}$. Kemudian dilanjutkan dengan proses demineralisasi dengan $\mathrm{HCl} 1 \mathrm{M}$ perbandingan 1:10 dan diaduk selama 30 menit pada suhu kamar. Campuran tersebut kemudian disaring dan residu dicuci dengan air demineral sampai netral. Hasil berupa kitin dari proses ini dikeringkan dalam oven pada temperatur $60^{\circ} \mathrm{C}$.

Kitosan dibuat dalam penelitian ini menggunakan metode deasetilasi alkali, yakni dengan menambahkan larutan natrium hidroksida $40 \%$ dengan perbandingan 1:10 pada kitin, kemudian dipanaskan sambil diaduk dengan 
magnetik strirer selama 1-3 jam pada temperatur $120^{\circ} \mathrm{C}$, setelah dingin dicuci dengan air demineral sampai netral kemudian dikeringkan hingga kering dalam oven pada suhu $40^{\circ} \mathrm{C}$. Kitosan yang diperoleh dikarekterisasi dengan spektrofotometer inframerah, serta penentuan Kadar $\mathrm{N}$ dengan metode Kjeldahl dan Penentuan Kadar $\mathrm{C}_{\text {organik}}$.

\section{Penentuan Kadar $\mathrm{C}_{\text {organik }}$}

Sampel kering sebanyak $0,5 \mathrm{~g}$ dimasukkan ke dalam labu takar $25 \mathrm{~mL}$ dan ditambahkan $5 \mathrm{~mL} \mathrm{~K} \mathrm{~K}_{2} \mathrm{Cr}_{2} \mathrm{O}_{7} 1 \mathrm{M}$ dan $5 \mathrm{~mL} \mathrm{H}_{2} \mathrm{SO}_{4}$ pekat. Campuran tersebut ditambahkan lagi $2,5 \mathrm{~mL}$ $\mathrm{H}_{3} \mathrm{PO}_{4} 85 \%$ dan $0,5 \mathrm{~mL}$ indikator feroin sebagai indikator kemudian diencerkan sampai volume tepat $25 \mathrm{~mL}$. Dari larutan yang terjadi diambil 2,5 $\mathrm{mL}$ dan diencerkan menjadi $10 \mathrm{~mL}$, lalu dititrasi dengan larutan $\mathrm{FeSO}_{4} .7 \mathrm{H}_{2} \mathrm{O}$ 1M sampai warna larutan berubah dari warna merah tua menjadi biru. Hal serupa dilakukan juga untuk blanko tanpa penambahan sampel.

\section{Preparasi Kitosan hidrogel dan pembuatan Kompleks Kitosan Hidrogel dengan Tembaga(II)}

Sampel kitosan dilarutkan dalam $10 \mathrm{~mL}$ larutan asam asetat glasial sehingga diperoleh larutan kitosan $6 \%$. Masing-masing campuran diaduk dan didiamkan sampai membentuk gel. Kitosan hidrogel dikarakterisasi dengan spektroskopi FTIR. Kitosan hidrogel diinteraksikan dengan larutan $\mathrm{Cu}^{2+} 500$ $\mathrm{mg} / \mathrm{L}$ dengan perbandingan 1:50 selama 12 jam dan setelah itu disaring menggunakan pompa vakum. Hasil yang diperoleh dikeringkan dalam oven pada suhu $40^{\circ} \mathrm{C}$. Kompleks kitosan hidrogel dikarakterisasi dengan spektrofotometer FTIR.

\section{HASIL DAN PEMBAHASAN Isolasi Kitin dan Kitosan}

Isolasi kitin dari cangkang kepiting melalui dua tahap yaitu deproteinisasi dan demineralisasi. Proses deproteinisasi dilakukan dengan menambahkan basa kuat yaitu $\mathrm{NaOH}$. Deproteinisasi dilakukan mengingat bahwa salah satu penyusun cangkang kepiting yang cukup besar adalah protein. Dengan demikian untuk memperoleh kitin yang murni maka perlu dilakukan penghilangan protein, sementara demineralisasi dilakukan untuk menghilangkan mineral-mineral yang ada dengan cara menggunakan asam klorida. Asam klorida akan melarutkan mineral yang ada. Reaksinya adalah sebagai berikut :

$$
\begin{gathered}
\mathrm{CaCO}_{3(\mathrm{~s})}+2 \mathrm{HCl} \rightarrow \mathrm{CaCl}_{2(\mathrm{l})}+\mathrm{H}_{2} \mathrm{O}_{(\mathrm{g})}+\mathrm{CO}_{2(\mathrm{~g})} \\
\mathrm{Ca}_{3}\left(\mathrm{PO}_{4}\right)_{2(\mathrm{~s})}+4 \mathrm{HCl}_{(\mathrm{l})} \rightarrow 2 \mathrm{CaCl}_{2(\mathrm{l})}+\mathrm{Ca}\left(\mathrm{H}_{2} \mathrm{PO}_{4}\right)_{2(\mathrm{I})}
\end{gathered}
$$

Pengolahan kitosan dapat dilakukan dengan proses deasetilasi menggunakan basa kuat pada temperatur yang cukup tinggi, yaitu $120^{\circ} \mathrm{C}$. Kondisi ini, akan menyebabkan gugus asetil yang ada pada kitin akan terlepas sehingga senyawa amida yang ada pada kitin berubah menjadi senyawa amina. Perubahan struktur inilah yang menghasilkan senyawa kitosan. Proses deasetilasi pada kitosan sekaligus juga sebagai proses lanjutan deproteinisasi dari kitin. Kitosan yang dihasilkan diharapkan mengandung protein seminimal mungkin.

Berdasarkan ketiga proses di atas dapat diketahui bahwa setiap proses yang dilakukan akan mengurangi berat sampel yang ada karena setiap proses yang dilakukan bertujuan untuk menghilangkan senyawa-senyawa yang tidak diinginkan dari sampel. Hal tersebut dapat terlihat dari data kitin dan kitosan yang dihasilkan seperti pada tabel 1 . 
Tabel 1. Kitin dan Kitosan dari cangkang kepiting

\begin{tabular}{ccccc}
\hline $\begin{array}{c}\text { Cangkang kepiting } \\
\text { (gram) }\end{array}$ & $\begin{array}{l}\text { Kitin } \\
\text { (gram) }\end{array}$ & $\%$ & \multicolumn{2}{c}{$\begin{array}{l}\text { Kitosan } \\
\text { (gram) }\end{array}$} \\
\hline 70 & 8,5 & 12,14 & 5 & 58,82 \\
\hline
\end{tabular}

Data yang diperoleh diketahui bahwa kitin pada penelitian ini mempunyai derajat deasetilasi sebesar $61,77 \%$ sedangkan kitosan mencapai 71,486\%. Proton Laboratories Inc. menyatakan bahwa kitosan memiliki derajat deasetilasi $\geq 70 \%$ maka dapat dinyatakan bahwa proses deasetilasi kitin pada penelitian sudah berhasil memperoleh polimer kitosan (Khan dkk, 2002).

Derajat deasetilasi kitin yang cukup besar menunjukkan bahwa pada kitin telah terjadi perubahan sebagian gugus amida menjadi amina. Hal ini dapat disebabkan karena proses deproteinisasi yang dilakukan sebanyak dua kali dimana setiap proses deproteinisasi memungkinkan terjadinya proses deasetilasasi. Demikian halnya pada kitosan dengan derajat deasetilasi yang belum terlalu tinggi menunjukkan bahwa masih adanya gugus amida yang belum terdeasetilasi akibat proses deasetilasi yang dilakukan hanya sekali saja.

\section{Karakterisasi Kitin dan Kitosan dengan Spektroskopi FTIR}

Spektra FTIR dari kitin dan kitosan menunjukkan gugus-gugus yang ada pada polimer-polimer tersebut. Pada kitin terdapat ulur $\mathrm{OH}$ pada bilangan gelombang 3448,1 $\mathrm{cm}^{-1}$ yang memunculkan pita lebar dengan intentitas yang kuat. Pada daerah bilangan gelombang ini seharusnya ulur $\mathrm{N}-\mathrm{H}$ juga muncul, tetapi karena tertutup oleh uluran $\mathrm{OH}$ yang lebih lebar maka ulur N-H tidak dapat diamati. Adanya ulur $\mathrm{N}-\mathrm{H}$ dapat diperjelas dengan adanya tekukan $\mathrm{N}-\mathrm{H}$ pada bilangan gelombang $1561,5 \mathrm{~cm}^{-1}$. Serapan pada bilangan gelombang $2938 \mathrm{~cm}^{-1}$ merupakan rentang $\mathrm{C}-\mathrm{H}$ dari metilen $\left(-\mathrm{CH}_{2}\right)$ dari rantai utama kitin yang berbentuk siklik. Adanya vibrasi ini diperjelas dengan adanya tekuk $\mathrm{C}-\mathrm{H}$ dari metil maupun metilen pada bilangan gelombang $1380 \mathrm{~cm}^{-1}$. Pada bilangan gelombang $1663,2 \mathrm{~cm}^{-1}$ terdapat rentang $\mathrm{C}=\mathrm{O}$ yang berasal dari gugus amida (-NHCO-). Sedangkan ulur C-N yang dihasilkan oleh gugus amida terdapat pada bilangan gelombang $1320 \mathrm{~cm}^{-1}$. Pada bilangan gelombang 1076,5 $\mathrm{cm}^{-1}$ terdapat rentang C-O. Rentang ini dihasilkan dari gugus metanol yang melekat pada rantai kitin.

Spektra FTIR kitosan menunjukkan adanya pergeseran beberapa gugus ke bilangan gelombang yang lebih kecil akibat proses deasetilasi yang juga sekaligus berfungsi sebagai proses deproteinisasi. Proses ini menyebabkan gugus-gugus kitosan lebih terbebas dari pengotor. Ulur $\mathrm{OH}$ teramati pada bilangan gelombang $3433,8 \quad \mathrm{~cm}^{-1}$ yang memunculkan pita yang lebar sehingga menutupi uluran $\mathrm{N}-\mathrm{H}$ yang seharusnya juga muncul pada daerah ini. Adanya ulur N-H diperjelas dengan adanya tekukan N-H pada bilangan gelombang $1563 \mathrm{~cm}^{-1}$. Tekukan N-H ini mengalami pergeseran ke daerah bilangan gelombang yang lebih besar akibat adanya proses deasetilasi yang mengubah sebagian gugus amida menjadi gugus amina. Lepasnya gugus amida menyebabkan massa tereduksi $\mathrm{N}$ $\mathrm{H}$ semakin kecil sehingga bilangan gelombang bergeser ke bilangan gelombang yang lebih besar. 


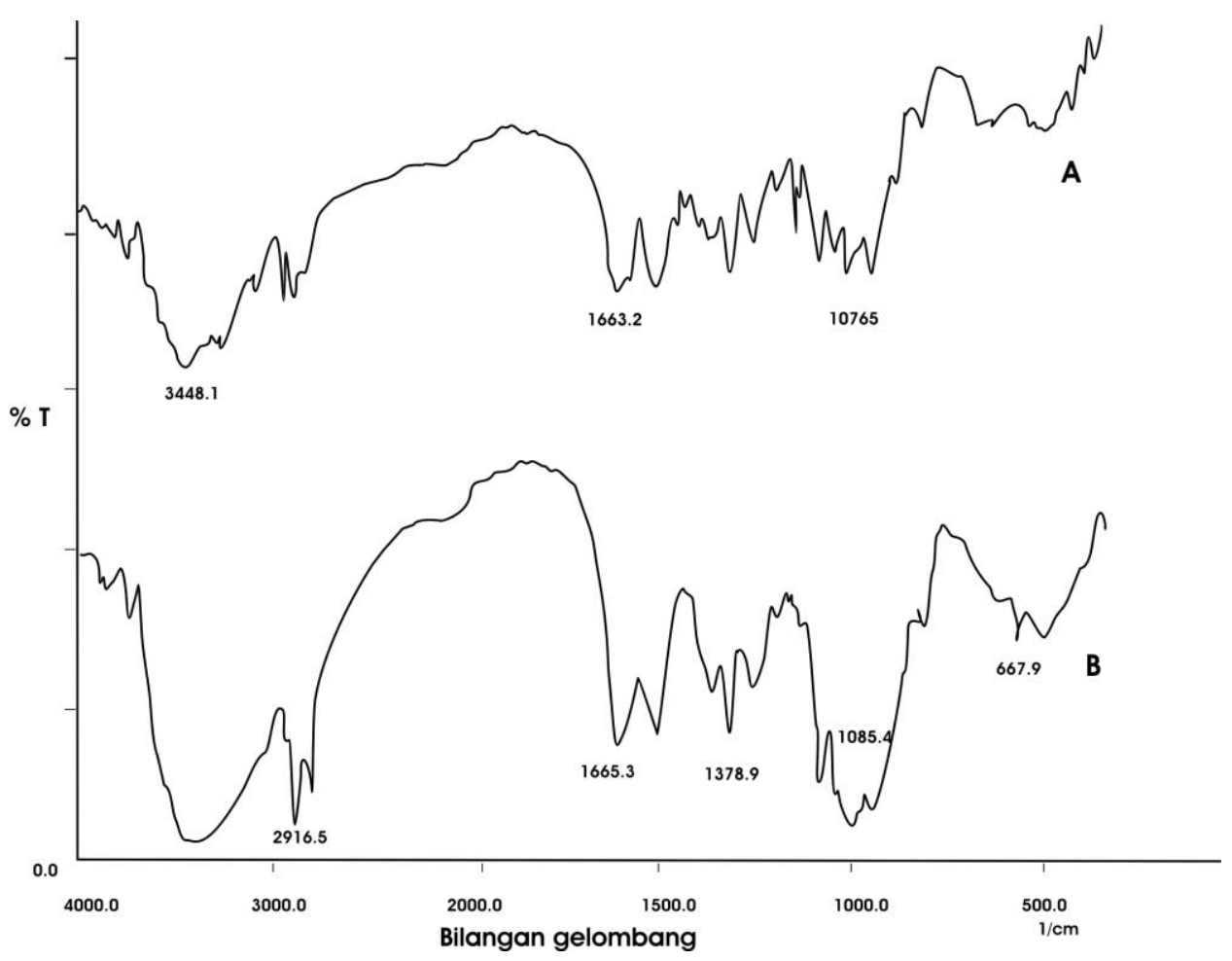

Gambar 3. Spektra FTIR (A) Kitin, (B) Kitosan

Serapan pada bilangan gelombang $1655,3 \mathrm{~cm}^{-1}$ adalah untuk rentang $\mathrm{C}=\mathrm{O}$ yang berasal dari gugus amida (-NHCO-) yang menunjukkan bahwa pada kitosan masih adanya gugus amida yang belum terdeasetilasi menjadi gugus amina. Pada bilangan gelombang ini terjadi sedikit peningkatan $\%$ transmitan yang menunjukkan melemahnya intensitas akibat berkurangnya kuantitas gugus $\mathrm{C}=\mathrm{O}$. Rentang $\mathrm{C}-\mathrm{H}$ dari metilen $\left(-\mathrm{CH}_{2}\right)$ juga muncul dari rantai utama kitosan yang berbentuk siklik pada bilangan gelombang 2916,9 rentang $\mathrm{C}-\mathrm{H}$ dari metilen $\left(-\mathrm{CH}_{2}\right)$ dari rantai utama kitin yang berbentuk siklik. Adanya vibrasi ini diperjelas dengan adanya tekuk C-H dari metil maupun metilen pada bilangan gelombang $1378 \mathrm{~cm}^{-1}$. Serapan pada bilangan gelombang $1310 \mathrm{~cm}^{-1}$ menandakan ulur untuk C-N dari amina maupun amida yang tersisa. Rentang C$\mathrm{O}$ yang terdapat pada bilangan gelombang $1085,4 \mathrm{~cm}^{-1}$ dihasilkan dari gugus metanol yang melekat pada rantai kitosan. Rentang ini mengalami pergeseran ke bilangan gelombang yang lebih besar menunjukkan semakin banyaknya ikatan hidrogen yang terbentuk pada kitosan.

\section{Penentuan kadar Nitogen total dan Karbon Organik ( $\mathbf{C}_{\text {organik }}$ )}

Penentuan kadar nitrogen dapat digunakan untuk membedakan kitin dan kitosan secara kuantitatif. Penentuan kadar nitrogen pada penelitian ini menggunakan metode Kjeldhal. Kitosan bersama katalis terlebih dahulu didestruksi menggunakan asam sulfat untuk membentuk ammonium sulfat. Hasil penelitian memperlihatkan adanya perbedaan warna pada ketiga larutan sampel, mulai dari jernih, sedikit gelap, sampai ke warna gelap. Data yang diperoleh menunjukkan bahwa kadar nitrogen yang diperoleh pada penelitian ini kurang lebih $7,9571 \%$. Berdasarkan pernyataan Widodo (2005) yang 
menyatakan bahwa kandungan nitrogen pada kitin $<7 \%$ dan pada kitosan $\geq 7 \%$, diketahui bahwa proses deasetilasi kitin sudah memenuhi standar menghasilkan polimer kitosan. dengan kadar nitrogen pada kitin, yaitu sekitar 2,483\% memperjelas perbedaan kandungan nitrogen pada kitin dan kitosan.

Penentuan kadar karbon dapat dilakukan dengan titrasi reduksioksidasi. Kadar karbon dapat juga digunakan untuk mengetahui keberhasilan proses deasetilasi kitin untuk menghasilkan kitosan. Titrasi menggunakan ferro sulfat menunjukkan bahwa volume titran yang dibutuhkan oleh blanko lebih banyak daripada volume yang dibutuhkan oleh sampel. Hal ini disebabkan karena tidak adanya reaksi dikromat dengan sampel pada larutan blanko sedangkan pada larutan sampel, dikromat yang dititrasi merupakan sisa dari reaksi dikromat dengan sampel. Dengan demikian dikromat yang harus dititrasi pada blanko jumlahnya lebih banyak daripada yang ada pada sampel. Dari data yang diperoleh diketahui bahwa kadar $\mathrm{C}_{\text {organik }}$ pada kitosan sebesar 2,767 $\%$. Bila dibandingkan dengan kadar $\mathrm{C}_{\text {organik }}$ pada kitin yang mencapai 3,598 $\%$, terlihat penurunan kadar $\mathrm{C}_{\text {organik }}$ akibat adanya proses deasetialsi pada proses pembuatan kitosan yang menghilangkan sebagian besar gugus asetil pada kitin.

\section{Karakterisasi Kompleks Kitosan Hidrogel dengan Tembaga(II)}

Pembentukkan kitosan hidrogel menyebabkan susunan kitosan menjadi lebih lentur yang mengakibatkan terjadinya pembesaran sudut-sudut ikatan sehingga bilangan gelombang gugus-gugusnya mengalami pergeseran ke bilangan gelombang yang lebih besar. Pada bilangan gelombang 3442,9 $\mathrm{cm}^{-1}$ terdapat ulur $\mathrm{O}-\mathrm{H}$ dengan pita yang agak tajam karena adanya uluran $\mathrm{N}-\mathrm{H}$ dengan intensitas sedikit lebih kuat dari ulur $\mathrm{O}-\mathrm{H}$ yang terhimpit pada daerah tersebut. Adanya uluran N-H diperjelas dengan tekukan $\mathrm{N}-\mathrm{H}$ dari $\mathrm{NH}_{3}{ }^{+}$dalam suasana asam pada bilangan gelombang $1594,7 \mathrm{~cm}^{-1}$.

Serapan pada bilangan gelombang 2918,4 $\mathrm{cm}^{-1}$ merupakan rentang $\mathrm{C}-\mathrm{H}$ dari metilen $\left(-\mathrm{CH}_{2}\right)$ juga muncul dari rantai utama kitosan hidrogel yang berbentuk siklik. Adanya vibrasi ini diperjelas dengan adanya tekuk $\mathrm{C}-\mathrm{H}$ dari metil maupun metilen pada bilangan gelombang $1409,6 \mathrm{~cm}^{-1}$. Rentang C $=\mathrm{O}$ muncul pada bilangan gelombang $1720 \mathrm{~cm}^{-1}$ dengan transmitan yang cukup besar. Kondisi ini menunjukkan semakin lemahnya intensitas gugus $\mathrm{C}=\mathrm{O}$ karena semakin sedikitnya kuantitas $\mathrm{C}=\mathrm{O}$, serta serapan pada bilangan gelombang $1156,3 \mathrm{~cm}^{-1}$ menandakan adanya ulur C-N dan pada bilangan gelombang 1091,5 $\mathrm{cm}^{-1}$ terdapat ulur $\mathrm{C}-\mathrm{O}$ dengan intensitas yang sangat kuat akibat adanya perubahan sudut ikatan glikosida yang cukup besar. Serapan pada bilangan gelombang $3500-3100 \mathrm{~cm}^{-1}$ tidak ditemukan puncak yang spesifik karena pada daerah ini terdapat uluran $\mathrm{O}-\mathrm{H}$ yang berhimpitan dengan ulur $\mathrm{N}-\mathrm{H}$, dimana pada $\mathrm{N}-\mathrm{H}$ tersebut telah terikat tembaga(II) sehingga ulur $\mathrm{N}-\mathrm{H}$ memiliki daerah pergeseran yang lebih lebar. Adanya uluran N-H yang terikat dengan tembaga(II) diperjelas dengan adanya tekukan $\mathrm{N}-\mathrm{H}$ yang mengalami pergeseran ke bilangan gelombang yang lebih kecil yaitu dari bilangan gelombang 1594,7 ke $1542,9 \mathrm{~cm}^{-1}$ akibat semakin besarnya massa tereduksinya. 


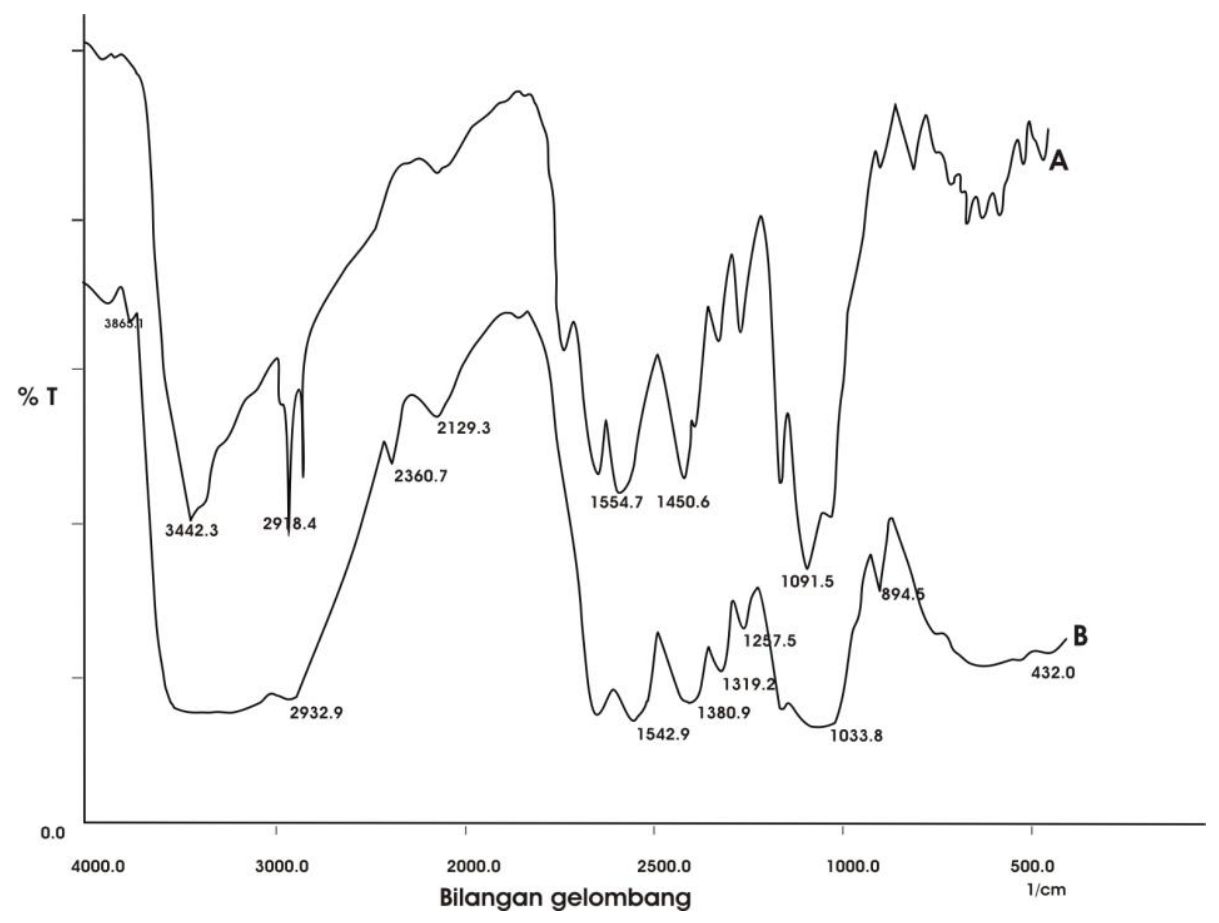

Gambar 4. Spektra FTIR (A) Kitosan Hidrogel, (B) Kompleks Kitosan Hidrogel-Tembaga(II)

Sementara pada bilangan gelombang $2923,9 \mathrm{~cm}^{-1}$ terdapat rentang $\mathrm{C}-\mathrm{H}$ dari metilen $\left(-\mathrm{CH}_{2}\right)$ juga muncul dari rantai utama kitosan hidrogel yang berbentuk siklik. Adanya vibrasi ini diperjelas dengan adanya tekuk $\mathrm{C}-\mathrm{H}$ dari metil maupun metilen pada bilangan gelombang $1380 \mathrm{~cm}^{-1}$. Ulur $\mathrm{C}=\mathrm{O}$ terdapat pada panjang gelombang 1655, sedangkan pada penjang gelombang $1033,8 \mathrm{~cm}^{-1}$ terdapat ulur CO. Pada bilangan gelombang $1257 \mathrm{~cm}^{-1}$ terdapat ulur $\mathrm{C}-\mathrm{N}$ yang mengalami pergeseran ke bilangan gelombang yang lebih besar karena terikatnya tembaga(II) pada gugus N-.

\section{KESIMPULAN}

Berdasarkan penelitian yang telah dilakukan maka dapat disimpulkan :

1. Isolasi kitin dan kitosan dari cangkang keping menghasilkan $12,14 \%$ dengan derajat deasetilasi $61,77 \%$ kitin dan 58,82\% kitosan dengan derajat deasetilasi 71,486\%, serta kadar $\mathrm{N}$ total dan $\mathrm{C}_{\text {organik }}$ pada kitosan sebesar $7,9571 \%$ dan $2,767 \%$.

2. Spektra FTIR dari kitosan menunjukkan adanya pergeseran tekuk N-H ke bilangan gelombang yang lebih besar yaitu dari bilangan gelombang $1561,5 \mathrm{ke} 1563 \mathrm{~cm}^{-1}$ dan meningkatnya $\% \mathrm{~T}$ dari gugus $\mathrm{C}=\mathrm{O}$, sedangkan spektra FTIR kitosan hidrogel secara umum menunjukkan pergeseran ke bilangan gelombang yang lebih besar akibat perubahan sudut-sudut ikatan kitosan yang semakin lentur.

3. Spektra FTIR dari kompleks kitosan hidrogel-tembaga(II) menunjukkan melebarnya daerah serapan uluran $\mathrm{N}-\mathrm{H}$ dan bergesernya tekukan N-H ke bilangan gelombang yang lebih kecil yaitu dari bilangan gelombang 1594,7 ke $1542,9 \mathrm{~cm}^{-1}$ akibat terikatnya tembaga(II) pada gugus N-. 


\section{DAFTAR PUSTAKA}

Berger,J., Reist, M., Mayer,J.,M., Felt, O., Peppas, N.,A., \& Gurny, R. 2004. Structure and Interactions in covalently and ionically crosslinked chitosan hydrogels for biomedical applications. Europen Journal of Pharmaceutics and Biopharmaceutics 57, 19-34.

Guibal, Eric. 2004. Interactions of Metal ions with Chitosan-based sorbents : a review. Separation and Purification technology 38, 43-74.

Khan, A.T., Peh, K.K., Ching, S.S., 2002. Reporting degree of deacetylation values of chitosan : the influence of analytical methods. J. Pharm Pharmaceut Sci 5 (3): 205-212.

Kopecky, Kopecka, Misikova. 2005. Sorption of Copper(II) on Chitosan from Solutions of Copper Sulphate, Copper Perchlorate, and Copper Nitrate. Acta Facultatis Pharmaceuticae Universitatis Comenianae. Bratislava.

Kumar, Ravi, N., V., Majeti. 2000. A review of chitin and chitosan applications. Reactive \& Functional Polymers 46, 1-27.

Marganof. 2002. Potensi Limbah Udang sebagai Penyerap Logam Berat (Timbal, Kadmium, dan Tembaga) di Perairan.

Mohadi R. 2004. Immobilisasi Asam Humat pada Kitin dan Aplikasinya untuk Mengikat Logam Ag(I). Thesis. UGM. Yogyakarta.

Ogawa, Kozo, Yui, Toshifumi, \& Kenji Okuyama. 2004. Three D structrures of chitosan. International Journal of Biological Macromolecules 34, 1-8.
Okuyama, K., Noguchi, K., Kanenari, M., Egawa, T., Osawa, K., \& Ogawa, K. 2000. Structural diversity of chitosan and its complexes. Carbohydrate Polymers 41, 237-247.

Pearson R. G. 1963. Hard and Soft Acid and Bases. Journal of American Chemical Society, vol 85, hal 35333539.

Varma, J., A., Deshpande, V., S., \& Kennedy, F., J. 2004. Metal Complexation by Chitosan and its derivatives : a review. Carbohydrate Polimers 55, 77-93.

Widodo, Agus, Mardiah, \& Prasetyo, Andy. Potensi Kitosan dari sisa Udang sebagai Koagulan Logam Berat Limbah Cair Industri Tekstil. ITS. Surabaya. 